\title{
紫色半導体レーザーを用いた光重合型レジン系材料の硬化とその特性
}

\author{
亀山敦史春山亜貴子 \\ 東京歯科大学口腔健康臨床科学講座 \\ (受付 : 2013 年 6 月 24 日, 受理 : 2013 年 7 月 23 日)
}

\section{Characteristics of Light-curing Resin-based Materials Cured by Violet Laser Diode}

\author{
Atsushi KAMEYAMA and Akiko HARUYAMA \\ Department of Clinical Oral Health Science, Tokyo Dental College
}

(Received: June 24, 2013, Accepted for Publication: July 23, 2013)

\begin{abstract}
The violet laser diode was developed in 1996, and is now widely used as a light source for high-speed multilayer recording systems such as Blu-ray discs and HD-DVD systems. These lasers also show promise for medical applications, such as cutting soft tissue, laser acupuncture, tooth whitening, and detection of dental caries. The wavelength of the violet laser diode (approx. 405nm) may be suitable for hardening light-cured dental materials combined with some alternative photoinitiators. This article examines the light-curing efficiency of some commercial and three experimental dental resins by GaNbased violet laser diode determined in terms of ultimate micro-tensile strength, in comparison with curing by various commercial LED light-curing units. The spectral characteristics of the transmittance of contemporary dental adhesives and the emission of several commercially available light-curing units are also presented. The results revealed that violet laser diodes can be used as a light-curing source to initiate the polymerization of light-cured dental resins.
\end{abstract}

(J. Jpn. Soc. Laser Dent. $24: 61 \sim 67,2013$ Reprint requests to Dr. KAMEYAMA)

Key words = violet laser diode, photoinitiator, ultimate micro-tensile strength, dental adhesive

キーワード=紫色半導体レーザー, 光増感剤, 微小引張り強さ, ボンディングレジン

\section{はじめに}

光重合型コンポジットレジンが修復材料として歯科臨床 の場に普及して久しいが, その需要は材料の進化に伴って 徐々に大きくなっている。特に国際歯科連盟（FDI）で 2000 年に採択された Minimal Intervention（MI）に関す る声明 ${ }^{1)}$ は, 今世紀の修復用材料の主流をコンポジットレ ジンに大きくシフトさせたといっても過言ではない。非常 に高い接着性と臼歯部修復にも耐えうる機械的強度, そし て患者の高い審美的要求にも十分応えることのできる豊富 な色調によって, 今やコンポジットレジン修復は前・臼歯 を問わずMI と審美性の回復・維持を兼ね備えることので きるファーストチョイスの硬組織修復材料となった。

コンポジットレジンやレジン系接着材料が発展してきた ように, その周辺機器もまた発展を遂げてきた。1974 年 頃, コンポジットレジンにカンファーキノン $(\mathrm{CQ}) /$ ア ン系の光重合開始剤が用いられて以降, ハロゲンランプを
光源とする可視光線照射器が長らく使用されてきた ${ }^{2-5)}$ 。 その後, キセノンランプを光源としたハイパワー型の可視 光線照射器も登場したが, 1991 年に中村修二ら（当時 日亜化学）が青色 LED を開発し6), 実用化されるように なると, 1998 年頃から徐々に歯科用可視光線照射器とし ての使用が試みられるようになった ${ }^{7,8)}$ 。青色 LED はその 波長域が 450 ～500nm であり，CQ の吸収波長と一致して いる5)。近年ではハロゲン系のものに取って代わり, LED 系照射器は光重合型レジンの重合用光源の主流となってき ている ${ }^{9,10)}$ 。

Nakamura らはさらに 1996 年, GaN 系紫色半導体レー

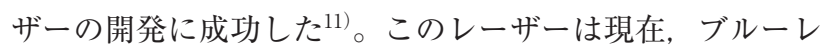
イディスクやHD-DVD など大容量化光ディスクシステム のキーデバイスとして工業界で広く応用されている年, 13)。 また, 医療や歯科医療の分野においても様々な応用が試み られている。

近年, ハロゲン系可視光線照射器での重合効率や審美性 


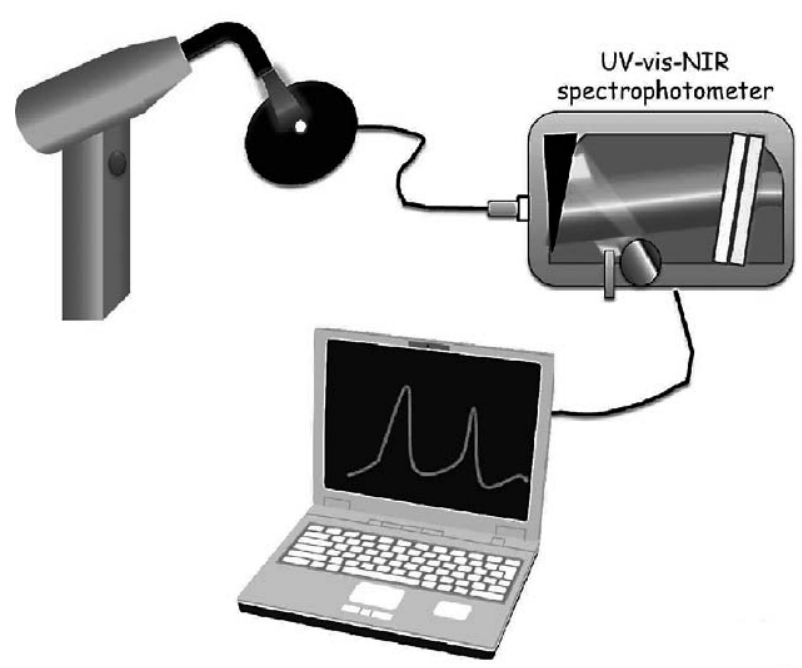

Fig. 1 Schematic illustration of the spectral measurement of light-curing unit ${ }^{17)}$

の向上を目的として, 従来の $\mathrm{CQ} /$ ア ミン系の重合開始剤の みならず，紫外線〜青紫領域に高い吸収波長を有する光重 合開始剂をも添加した光重合型レジン系材料が市販される ようになった ${ }^{5,15,16)}$ 。これらの背景を鑑みて, 我々は光重 合型レジン材料の重合用光源としても紫色半導体レーザー を応用できるのではないか，またもし可能であるとするな らば，このレーザーは出力やプローブを変えるだけで検査 から種々の治療に至るまで幅広く使用できる, 非常に汎用 性の高い歯科用機器になりうるのではないかと考えた。

本稿は, GaN 系青紫色半導体レーザーの光重合型レジ ン材料の重合用光源としての応用を想定して行ったこれま での研究成果をまとめたものである17-19)。

\section{歯科領域における紫色半導体レーザー応用の可能性}

現在, 紫色半導体レーザーは $405 \mathrm{~nm}$ 付近にピークを有 するものが広く応用されている。この波長域の光はへモグ ロビンやメラニン色素により大きく吸収されることから， 軟組織用レーザーメスとして応用した場合，近赤外領域の 波長を有するレーザーに比べて比較的低出力で蒸散や切開 が可能であり，また高い止血効果も期待できる ${ }^{20)}$ 。

歯周病原菌である Porphyronomas gingivalis（P.g.) は ポルフィリンを産生する。このポルフィリンは $400 \mathrm{~nm}$ 付近 の波長域に強い吸収ピークを有することが知られている。 Kotoku らはこの特徴に着目し, 紫色半導体レーザーによる P.g. 菌の殺菌効果を検証した。その結果, $200 \mathrm{~mW} / \mathrm{cm}^{2}, 10$ 秒 $\left(2.0 \mathrm{~J} / \mathrm{cm}^{2}\right)$ の比較的小さな出力での照射でもコントロー ルに比べて $50 \%$ 以上生菌率が低いことを見出し, その殺菌 効果を確認した ${ }^{21)}$ 。さらに, このポルフィリンに紫光を照

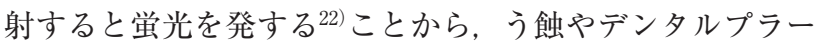
クの検知機器としての使用も試みられている23)。
近年, 二酸化チタンを配合させた歯科用過酸化水素漂白 剂が製品化されている。通常, 歯科臨床で行うオフィスブ リーチングでは $35 \%$ 程度の高濃度過酸化水素が用いられ ているが，二酸化チタン配合の漂白剤が光触媒として働く ため, $380 \sim 420 \mathrm{~nm}$ の光で活性化させることにより, 過 酸化水素を低濃度に抑えつつ, 高濃度過酸化水素剂に近似 した漂白効果を得ることが可能である ${ }^{24-29)}$ 。

その他にもレーザー銊 ${ }^{30)}$ や腫瘍細胞の細胞増殖抑制 311 など，一般医科領域での応用についても各方面で検討が行 われている。

\section{各種市販光照射器と比較した 紫色半導体レーザーの発振波長 ${ }^{17)}$}

現在市販され臨床で広く使用されている各種光照射器お よび紫色半導体レーザーの分光波長分布を分光放射照度計 (USB4000, Ocean Optics, Dunedin, FL, USA) で計測し た (Fig. 1) ${ }^{17)}$ 。その結果, ハロゲン系光照射器である Jetlite 3000 (J. Morita USA, CA, USA), ニューライト VL-2 (ジーシー, 東京), D-Lux 2000 (デントレード, 大阪）の波 長带域には若干の違いはあるものの，いずれも380〜 510nm にあることがわかった。またピーク波長は Jetlite 3000 とニューライト VL-2 で 491nm, D-Lux 2000 で 473nm であった。

キュアノス（松風，京都）は青色 LED を用いた光照射 器である。ピーク波長は $462 \mathrm{~nm}$ とハロゲン系より短く, また波長帯域は $430 〜 500 \mathrm{~nm}$ 付近であり， 八ロゲン系の ものに比べて特に短波長側で狭かった。1 ステップ薄膜レ ジン接着システムの $\mathrm{AQ}$ ボンド（サンメディカル, 守山） は開発当初, 薄膜でも拡散したモノマーが酸素による重合 阻害を受けず，確実に重合硬化することを目的に，CQ 以 外の光重合開始剤を用いていた。しかしながらこの反応帯 域が青色 LED 系照射器とミスマッチであったために重合 硬化せず, 結果として非常に低い接着強さを示したとの報 告がある ${ }^{32)}$ 。の結果を受けて, CQ と併用できて, かつ 高い重合性を示す新たな重合開始システムを採用した $\mathrm{AQ}$ ボンドプラスが開発された経緯がある ${ }^{16)}$ 。また青色 LED のみを用いた光照射器を用いた場合, $\mathrm{CQ}$ と他の開始剂と を併用している接着システムの接着強さはハロゲン系照射 器に比べて有意に低かったとの報告がある ${ }^{32}$ 。

Gライトプリマ (ジーシー, 東京) やブルーフェーズ G2 (Ivoclar Vivadent, Schaan, Liechtenstein) は, 青色 LED を用いた照射器にみられるこれらの短所を補うべく, 青色 LED に加えて紫色 LED も搭載した, いわゆるデュアルピー ク型の LED 照射器である ${ }^{5,33)}$ 。両者の照射器では波長帯域 が若干異なり, Gライトプリマでは $462.9 \mathrm{~nm}$ と $402.9 \mathrm{~nm}$, ブルーフェーズ G2 では 454.6nm と 410.3nm にそれぞれピー クを有していた。 


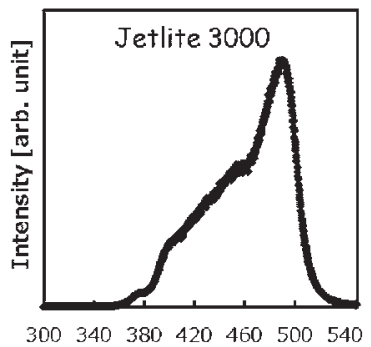

Wavelength [nm]

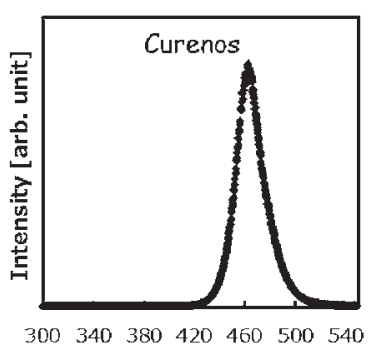
Wavelength $[\mathrm{nm}]$

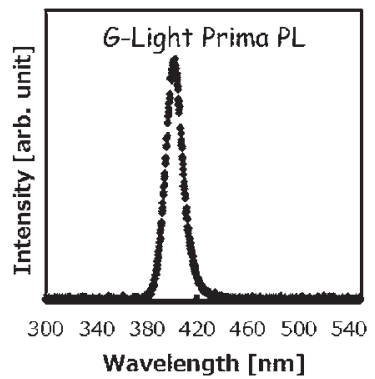

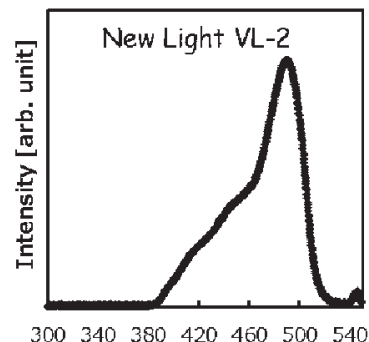

Wavelength [nm]

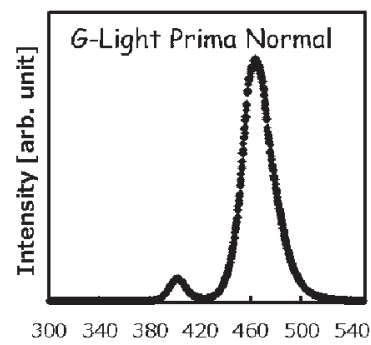
Wavelength $[\mathrm{nm}]$

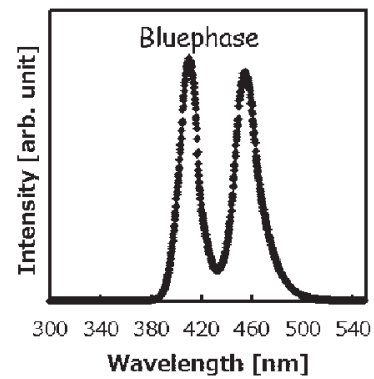

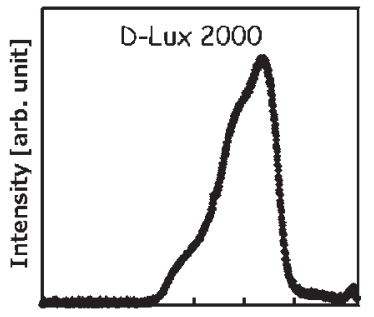

$300 \quad 340 \quad 380 \quad 420460 \quad 500 \quad 540$ Wavelength [nm]

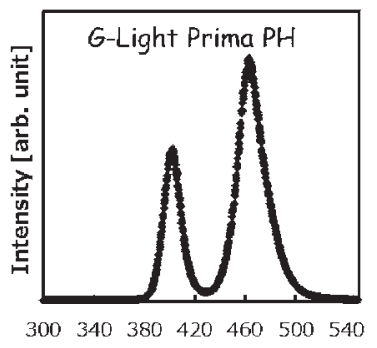
Wavelength $[\mathrm{nm}]$

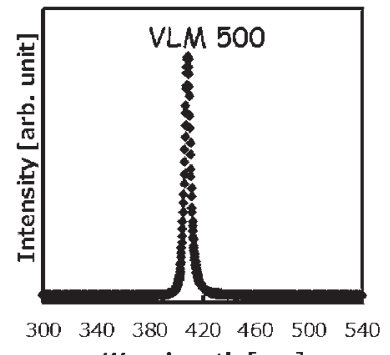

Wavelength $[\mathrm{nm}]$

Fig. 2 Emission spectra of light-curing unit ${ }^{17)}$

一方で, 本研究で用いた $\mathrm{GaN}$ 系紫色半導体レーザー （VLM 500, 住友電気工業, 横浜）はこれらの照射器とは 異なり, $409 \mathrm{~nm}$ 付近にピークを持ち, ピーク波長の $8 \mathrm{~nm}$ 前後に限られた非常に幅の狭い波長帯域を有する光源で あった (Fig. 2) ${ }^{18)}$ 。

市販ボンディングレジンの光透過特性 ${ }^{17,18)}$

光重合型の歯科用材料を用いてより質の高い臨床を行う ためには, 自分が日常臨床で用いている光照射器がどの程 度の波長帯域を有する光源であるかを知るとともに，用い る歯科材料がどの程度の波長帯域に反応可能かをも知る必 要がある。そこで我々は, 市販されている 11 種類の市販 ボンデイングレジンと, 実験当時に開発中であった試作ボ ンディングレジン 1 種類について, 光の透過特性を検討し た（Fig. 3)。一般に，ボンディングレジンは透明性が高 いため, 高い光透過性を示す場合には吸光度が低い, すな わち光増感性が低いことを意味する。逆にボンディングレ ジンに照射した光の透過が小さい場合には, すなわち光増 感性が高いことを意味する。

非常に認識しにくいものの, 各種ボンディングレジンの透
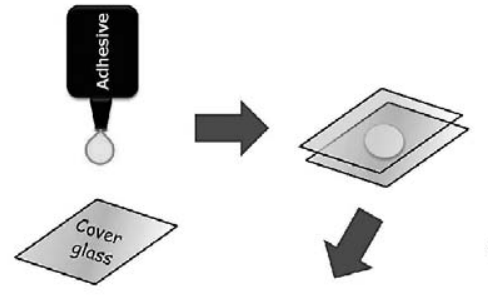

UV-vis-NIR spectrophotometer

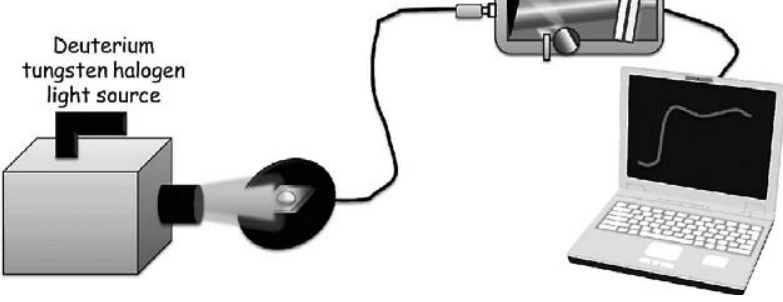

Fig. 3 Schematic illustration of the spectral measurement of dental adhesive ${ }^{17}$

過スペクトルには, $470 \mathrm{~nm}$ 付近の部分を中心に, 広波長帯 域にわたる若干の透過性の減少が確認できた。この凹みは $\mathrm{CQ}$ に起因するものであると思われるが，その凹みが非常に 小さいものであることから, $\mathrm{CQ}$ 単独での光増感性はわずか 

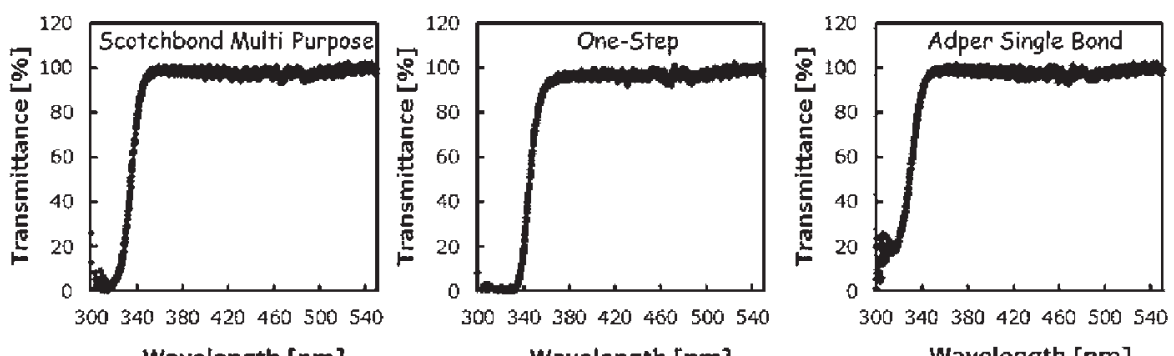

Wavelength $[\mathrm{nm}]$
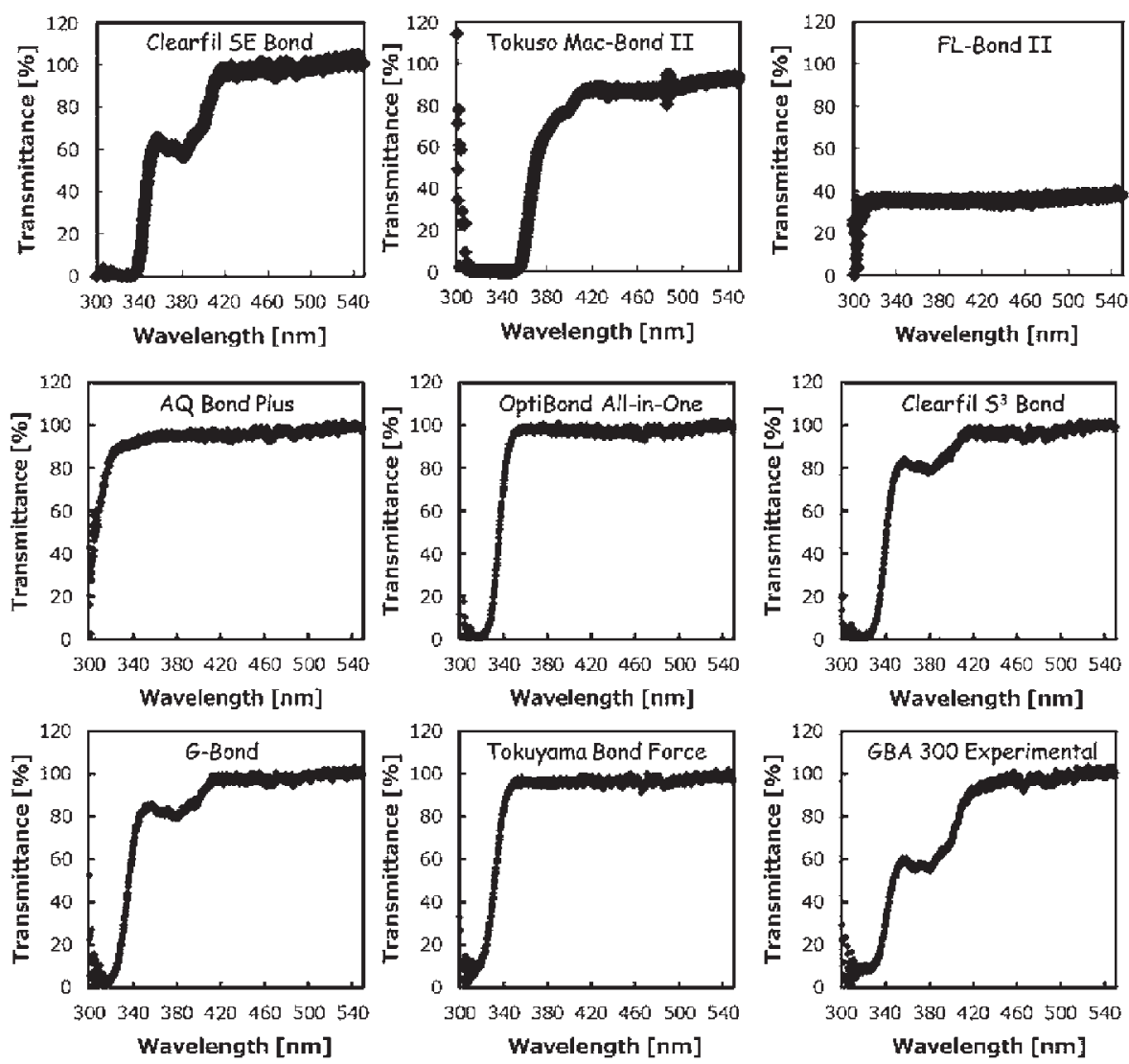

Fig. 4 Transmittance spectra of 12 dental adhesives ${ }^{17,18)}$

なものであった。この結果は過去の報告と同様である ${ }^{34,35) 。}$ 一方, クリアフィルメガボンド（海外製品名 Clearfil SE Bond), クリアフィルトライエスボンド（海外製品名 Clearfil S $\mathrm{S}^{3}$ Bond, 以上 クラレノリタケデンタル, 東京), G-ボンド（海外製品名 G-Bond），および試作ボンディング レジン GBA 300 (以上ジーシー, 東京) の 4 種類では, CQ に起因すると思われるわずかな透過性の低下とともに, 355 〜 410nm 付近に特徵的な 3 つの下向きピークを有する透過 性の減少域が存在した。このことから, これら 4 種類のボン デイングレジンでは紫色の波長帯域を有する光を照射するこ とで極めて高い重合反応を示すことが推測できた（Fig. 4）。

なお，フルオロボンドII（海外製品名 FL-Bond II，松 風，京都）は他のボンディングレジンとは全く異なる波形
を示し，全波長域において 40\%程度の低い光透過性を示し た。これは S-PRG フィラーの配合によりボンディングレジ ン自体の透過性が著しく低いため, 照射した光が散乱や反 射した結果であり，ボンディングレジン自体の光増感性が 高いこととは意味が異なる。

紫色半導体レーザーで硬化させた 市販ボンディングレジンの微小引張り強さ18)

前述のように，ボンディングレジンのうち，470nm 付 近より 410nm 付近の光を強く吸収するものについては紫 色半導体レーザーでも重合可能であることが推測される。 そこで，先の実験で実際に異なる光透過性を示した 3 種類 の市販ボンディングレジンを厚さ $0.6 \mathrm{~mm}$ のアクリルリン 
グ内に滴下し, 紫色半導体レーザー, 青色 LED 型光照射 器, およびデュアルピーク型 LED 光照射器で硬化させた あと砂時計型に試料を成形し, その微小引張り強さを比較 した (Fig. 5)。なおこの際, 紫色半導体レーザーは比較 する 2 種類の照射器の出力とほぼ同様になるよう, 事前に 調整した。

青色 LED 型光照射器であるキュアノス（松風, 京都) を 用いた場合, クリアフィルメガボンド（Clearfil SE Bond） の微小引張り強さは $65.1 \pm 8.2 \mathrm{MPa}$ であったが, 紫色半導体

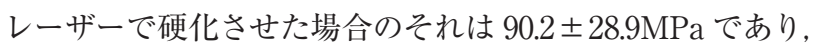
キュアノスで硬化させた場合に比べて有意に高い值を示し た（Table 1)。クリアフィルメガボンドでは, 463nmでの 光透過率に比べて $409 \mathrm{~nm}$ で小さいことから, 青色 LED よ りむしろ紫色光を効率的に吸収できたためにこのような結 果になったものと考えられる (Table 2)。したがって, ク リアフィルメガボンドは青色 LED のみではやや硬化が不十 分となる可能性があるが, むしろ紫色の光源を用いること で硬化がより確実に起こる可能性が示唆された。

トクソーマックボンド II とフルオロボンド IIはいずれも 光増感剤として $\mathrm{CQ}$ のを用いている。この 2 種類につい ては, 青色 LED系照射器であるキュアノス, デュアルピー ク型である G-ライトプリマ, および紫色半導体レーザーの 3 種類で有意差を認めなかった。したがって, 409nm に ピーク波長を有する紫色レーザーでも，現在用いられてい る光照射器と同等の $1000 \mathrm{~mW} / \mathrm{cm}^{2}$ 程度の出力をもってす

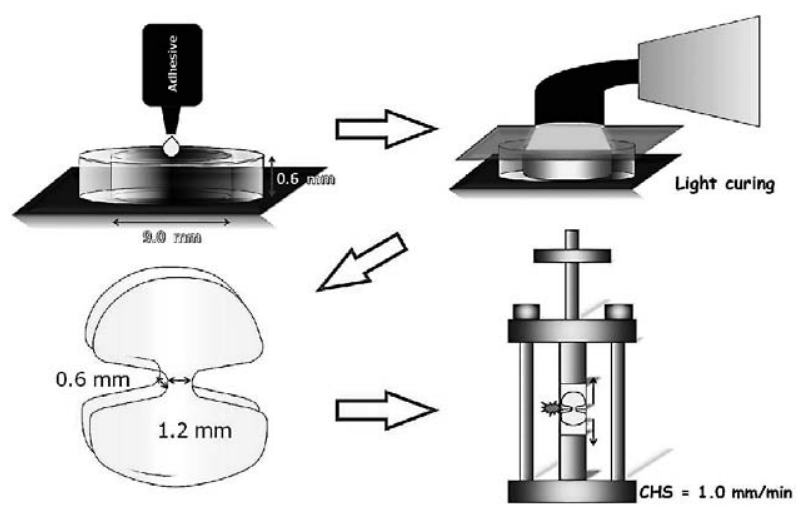

Fig. 5 Schematic illustrating specimen preparation and microtensile strength testing ${ }^{18,19)}$
れば, $\mathrm{CQ}$ のを光増感剂に用いたボンディングレジンで も十分に硬化できることがこの結果から明らかとなった。

\section{光増感剤の違いによる紫色半導体レーザーおよび 各種重合用光源との反応性の比較}

クリアフィルメガボンド（クラレノリタケデンタル, 東 京）では, 紫色半導体レーザーによる硬化体の機械的性質 が青色 LED 型照射器に比べて高かった。このことは, ク リアフィルメガボンドと同様の光増感剤を用いることで紫 色半導体レーザーをレジンの重合用光源として用いること が可能であることを示唆している。しかしながら, 製造者 側はクリアフィルメガボンド（クラレノリタケデンタル, 東京）に含まれる光増感剂の詳細を公表していない ${ }^{32)}$ 。そ こで, 次の実験として現在市販光重合型レジン系材料に用

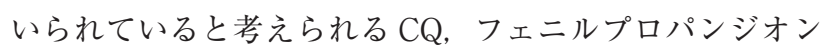
$(\mathrm{PPD})^{36)}$ ， モノアシルフォスディンオキサイド $(\mathrm{MAPO})^{37)}$ のいずれかを $1 \%$ 添加したノンフィラーレジンを試作し（そ れぞれ Exp-CQ, Exp-PPD, Exp-MAPO), 各種重合用光 源で硬化させた際の微小引張り強さを先の実験と同様の方 法で行った。あわせて, それぞれのノンフィラーレジンの 光透過性についての分光スペクトルもあわせて計測した。

Exp-CQ をキュアノス（松風, 京都) で硬化させた場合, 硬化体の微小引張り強さは $101.2 \pm 13.7 \mathrm{MPa}$ であった。し かしながら, Exp-MAPO ではその強さが $49.9 \pm 7.0 \mathrm{MPa}$ に過ぎず，有意に低い值となった（Table 3)。また，キュ アノス (松風, 京都) のピーク波長 $(463 \mathrm{~nm})$ における Exp-MAPO の光透過率の減少は極めて小さかったことか ら, MAPO のみを含むレジンを青色 LED 系光照射器で重 合させてもその反応は小さく，このため十分な機械的性質 が得られないことが明らかとなった。

G-ライトプリマ（ノーマルモード； ジーシー, 東京）を

Table 2 Reduction rate of light transmittance ${ }^{18)}$

\begin{tabular}{lrr}
\hline & $409 \mathrm{~nm}$ & $463 \mathrm{~nm}$ \\
\hline Clearfil SE Bond & $4.7 \%$ & $12.8 \%$ \\
FL-Bond II & $65.3 \%$ & $64.5 \%$ \\
Tokuso Mac-Bond II & $8.1 \%$ & $9.7 \%$ \\
\hline
\end{tabular}

Table 1 Ultimate micro-tensile strength ( $\mu \mathrm{TS}$ ) per group (MPa). Results with the same superscript letter represents no statistically difference $(n=10$; Tukey HSD test, $\mathrm{p}>0.05)^{18)}$.

\begin{tabular}{lccc}
\hline & Curenos & G-Light Prima (Normal) & VLM 500 \\
\hline Clearfil SE Bond & $65.1 \pm 8.2^{\mathrm{bc}}$ & $70.2 \pm 15.6^{\mathrm{ab}}$ & $90.2 \pm 28.9^{\mathrm{a}}$ \\
FL-Bond II & $39.1 \pm 2.5^{\mathrm{d}}$ & $31.4 \pm 6.4^{\mathrm{d}}$ & $43.7 \pm 6.7^{\mathrm{cd}}$ \\
Tokuso Mac-Bond II & $83.4 \pm 20.6^{\mathrm{ab}}$ & $66.7 \pm 12.8^{\mathrm{abc}}$ & $82.2 \pm 28.0^{\mathrm{ab}}$ \\
\hline
\end{tabular}


Table 3 Ultimate micro-tensile strength ( $\mu \mathrm{TS}$ ) per group (MPa). Results with the same superscript letter represents no statistically difference $(n=10 \text {; Tukey HSD test, } \mathrm{p}>0.05)^{19)}$.

\begin{tabular}{lcccc}
\hline & Curenos & G-Light Prima (Normal) & G-Light Prima (PL mode) & VLM 500 \\
\hline Exp-CQ & $101.2 \pm 13.7^{\mathrm{a}}$ & $102.1 \pm 18.1^{\mathrm{a}}$ & $72.8 \pm 16.3^{\mathrm{bc}}$ & $97.9 \pm 21.9^{\mathrm{a}}$ \\
Exp-PPD & $87.2 \pm 18.9^{\mathrm{ab}}$ & $99.4 \pm 24.7^{\mathrm{a}}$ & $69.4 \pm 13.7^{\mathrm{bc}}$ & $92.2 \pm 9.9^{\mathrm{ab}}$ \\
Exp-MAPO & $49.9 \pm 7.0^{\mathrm{c}}$ & $92.5 \pm 13.1^{\mathrm{ab}}$ & $86.5 \pm 21.2^{\mathrm{ab}}$ & $80.3 \pm 6.3^{\mathrm{ab}}$ \\
\hline
\end{tabular}

用いて硬化させた場合の Exp-CQの微小引張り強さは, キュアノスで硬化させた場合とほぼ同等であった。一方で, Exp-MAPO の微小引張り強さはキュアノスの場合に比べ て有意に高く，また Exp-CQ，Exp-PPD，Exp-MAPO の間 に有意差を認めなかった。G-ライトプリマ（ジーシー，東 京）では， 3 個の青色 LED と 1 個の紫色 LED が搭載され ており, Exp-MAPO での高い微小引張り強さは紫色 LED との反応に起因しているものと考えられた。

G-ライトプリマ（ジーシー，東京）のPL モードは, 3 つ の青色 LED を起動させず，紫色 LED のみを励起させる モードであり，そのパワー密度は約 $50 \mathrm{~mW} / \mathrm{cm}^{2}$ と極めて小 さい。しかしながら, MAPO の $405 \mathrm{~nm}$ 付近における量子 収率は CQ の 470nm における量子収率の 10 倍以上である との報告もあり ${ }^{38)}$ ，また本研究における Exp-MAPOの紫 色光領域での光透過性をみても約 15\%減少していることか ら，紫色領域の光を用いれば MAPO は効率よく硬化性を 示すことが推測される（Fig. 6)。実際，G-ライト（PL モー ド ; ジーシー, 東京）は極めて弱い紫色光にもかかわらず Exp-MAPO は十分に硬化し, その微小引張り強さは比較 的高い值を示した。

本実験では, 紫色半導体レーザー（VLM 500, 住友電気 工業, 横浜) のパワー密度をキュアノス（松風, 京都）や G-ライトプリマ（ノーマルモード；ジーシー，東京）とほぼ 同等になるよう，ノンフィラーレジン表層付近で $1350 \mathrm{~mW} /$ $\mathrm{cm}^{2}$ になるように設定した。つまり，この設定は G-ライト プリマ（PL モード ; ジーシー, 東京) の約 26 倍のパワー 密度に相当することから, 紫色半導体レーザーで Exp-MA$\mathrm{PO}$ を硬化させると両者の反応は極めて効率的に進み, 高い 微小引張り強さを示すものと思われた。しかし，実際には $80.3 \pm 6.3 \mathrm{MPa}$ の微小引張り強さにすぎず, G-ライト (PL モード ; ジーシー, 東京) と同程度であった。これは，あま りにレーザー光と MAPO との反応効率が高すぎ，一瞬に重 合反応が開始されるためポリマー鎖が短くなってしまった ことがその原因であると考えられた。

Chen らの報告によると，410nm における CQ の吸光係 数は $470 \mathrm{~nm}$ の約 $19 \%$ 程度である ${ }^{39)}$ 。したがって, G-ライ トプリマ（PL モード；ジーシー，東京）でExp-CQが低い 微小引張り強さを示したのは，その重合が不十分であった ためと考えられる。しかしながら，VLM 500 (住友電気工

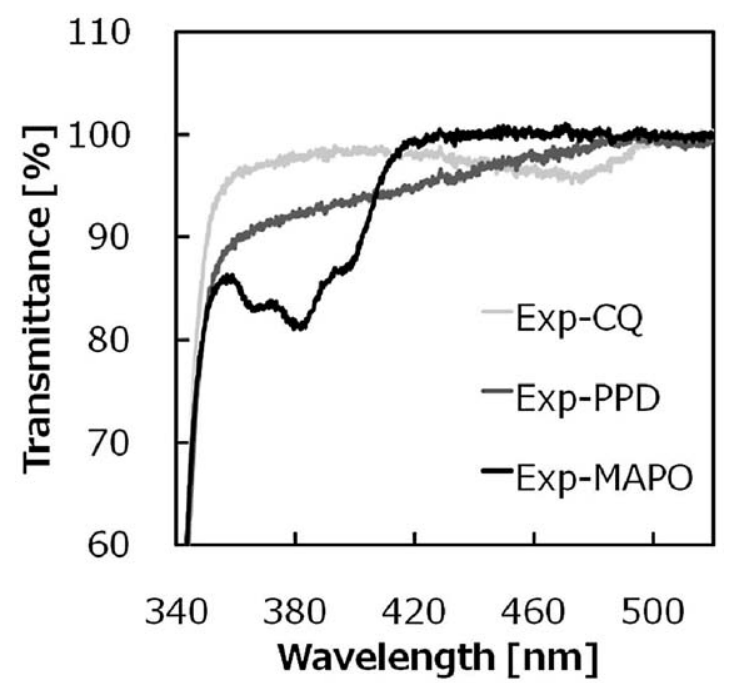

Fig. 6 Transmittance spectra of Exp-CQ, Exp-PPD, and Exp$\mathrm{MAPO}^{19)}$

業，横浜）における Exp-CQ の微小引張り強さは G-ライト プリマ（PL モード； ジーシー，東京）に比べて有意に高く, $97.9 \pm 21.9 \mathrm{MPa}$ であったことから，たとえ $\mathrm{CQ}$ のをを光増 感剂に用いている場合でも，高いパワー密度と十分な照射 時間によって，レジン系材料を十分に硬化させることがで きることが明らかとなった。

\section{まとめ}

本研究では, 紫色半導体レーザー（VLM 500, 住友電 気工業，横浜）を用いて市販ボンディングレジンや各種光 増感剂を含有した試作ノンフィラーレジンを硬化させ，そ の微小引張り強さを各種光照射器と比較した。その結果, 本レーザーは歯科用光重合型レジンの重合用光源としても 使用できる可能性が示唆された。現在，本レーザーに使用 している導光用ファイバーは $800 \mu \mathrm{m}$ と非常に細いため, このままでは光重合型歯科材料への応用は困難である。し かし，目的に合わせた先端チップやプローブを開発するこ とで, 本レーザーは非常に沉用性の高い歯科用機器になり うるものと思われる。

\section{謝 辞}

本研究の一部は, 科学研究費補助金若手研究（B）課題番号 
21791864 および基盤研究（C）課題番号 25462966 の援助を受け たことを付記し，謝意を表します。

\section{文献}

1) Tyas MI, Anusavice KJ, Frencken JE, et al: Minimal intervention dentistry - a review. FDI commission project 1-97. Int Dent J, 50: 1-12, 2000.

2) Taira M, Urabe H, Hirose T, et al: Analysis of photo-initiators in visible-light-cured dental composite resins. J Dent Res, 67: 24-28, 1988

3) Jakubiak J, Allonas X, Fouassier JP, et al: Camphorquinoneamines photoinitiating systems for the initiation of free radical polymerization. Polymer, 44: 5219-5226, 2003.

4) 角田 満：可視光線重合型コンポジットレジン修復法の歯髄 に及ぼす影響およびその歯髄保護法について一ゲラダヒヒ歯 髄，ヒト歯髄を用いた場合一。歯科学報， $86 ： 627-673,1986$.

5) Jimenez-Planas A, Martin J, Abalos C, et al: Developments in polymerization lamps. Quintessence Int, 39: e74-e84, 2008.

6) Nakamura S, Mukai T, Senoh M: High-power GaN p-n junction blue light emitting diodes. Jpn J Appl Phys, 30 : L1998-L2001, 1991.

7）藤林久仁子, 石丸和俊, 河野 篤：青色発光ダイオードを応 用した照射器に関する研究 第 1 報 基礎的研究. 日歯保存 誌, 39：180-188, 1996.

8) Whitters CJ, Girkin JM, Carey JJ: Curing of dental composites by use of InGaN light emitting diodes. Opt Lett, $24: 67-68,1999$.

9) Antonson SA, Antonson DE, Hardigan PC: Should my new curing light be an LED? Oper Dent, $33:$ 400-407, 2008.

10) Hedge V, Jadhav S, Aher GB: A clinical survey of the output intensity of 200 light curing units in dental offices across Maharashtra. J Conserv Dent, 12 : 105-108, 2009.

11) Nakamura $S$, Senoh $M$, Nagahama $S$, et al: InGaN-based multi-quantum-well-structure laser diodes. Jpn J Appl Phys, 35 : L74-L76, 1996.

12) Moon JH, Han HS, Shul YG, et al: A study on UV-curable coatings for HD-DVD: primer and top coats. Prog Org Coat, $59: 106-114,2007$.

13）石田昌宏，持田篤範，長谷川義晃，他：Blu-ray Disc 用 GaN 系 青紫色半導体レーザー. Panasonic Tech J, 54:26-30, 2008.

14) Hatayama $H$, Inoue $A$, Kato J: Study on use of blue-violet laser diode module as dental/oral surgical device. SEI Tech Rev, $66: 142-146,2008$.

15) Kameyama A, Kato J, Yoshinari M, et al: Ultimate microtensile strength of dental adhesives cured at different light source. J Photopolym Sci Technol, 21 : 31-35, 2008.

16）田代幸一, 松澤紀彦, 小里達也, 他：新規薄膜ボンディング 材の光重合性と歯質接着性一特に高出力型 LED 系光照射器 の影響について一。 日歯保存誌, $47: 642-649,2004$.

17) Kameyama A, Hatayama H, Kato J, et al: Spectral characteristics of light-curing unit and dental adhesives. J Photopolym Sci Technol, 24 : 411-416, 2011.

18) Kameyama A, Kato J, De Munck J, et al: Light-curing efficiency of dental adhesives by gallium nitride violet-laser diode determined in terms of ultimate micro-tensile strength. Bio-Med Mater Eng, 21 : 347-356, 2011.

19) Kameyama A, Hatayama H, Kato J, et al: Light-curing of dental resins with $\mathrm{GaN}$ violet laser diode: The effect of photoinitiator on mechanical strength. Lasers Med Sci, 26 : 279-283, 2011.

20) Kato J, Hatayama J, Miyazaki G, et al: Surgical performance of a 405-nm diode laser in treatment of soft tissue. Laser Phys Lett, $5: 316-320,2008$.
21) Kotoku Y, Kato J, Akashi G, et al: Bactericidal effect of a 405-nm diode laser on Porphyromonas gingivalis. Laser Phys Lett, 6 : 388-392, 2009.

22) Melanson JE, Lucy CA: Violet (405nm) diode laser for laser induced fluorescence detection in capillary electrophoresis. Analyst, 125 : 1049-1052, 2000.

23) Lennon AM, Buchalla W, Seitalski L, et al: Residual caries detection using visible fluorescence. Caries Res, $36: 315^{-}$ 319,2002

24）中澤妙衣子, 加藤純二, 平井義人：二酸化チタン含有低濃度 過酸化水素剂の漂白効果 高濃度過酸化水素剂との比較. 日 歯保存誌, $50: 373-378,2007$.

25) Sakai K, Kato J, Kurata H, et al: The amounts of hydroxyl radicals generated by titanium dioxide and $3.5 \%$ hydrogen peroxide under 405-nm diode laser irradiation. Laser Physics, 17 : 1062-1066, 2007.

26) Sakai K, Kato J, Nakazawa T, et al: Bleaching effect of a 405-nm diode laser irradiation used with titanium dioxide and $3.5 \%$ hydrogen peroxide. Laser Physics, $17: 1166-1170$, 2007.

27) Suemori T, Kato J, Nakazawa T, et al: A new non-vital tooth bleaching method using titanium dioxide and 3.5\% hydrogen peroxide with a 405-nm diode laser or a halogen lamp. Laser Phys Lett, 5 : 454-459, 2008.

28) Suyama Y, Otsuki M, Ogisu S, et al: Effects of light sources and visible light-activated titanium dioxide photocatalyst on bleaching. Dent Mater J, $28: 693-699,2009$.

29) Tano E, Otsuki M, Kato J, et al: Effects of 405nm diode laser on titanium oxide bleaching activation. Photomed Laser Surg, 30:648-654, 2012.

30) Litscher G, Wang L: Biomedical engineering meets acupuncture-development of a miniaturized 48-channel skin impedance measurement system for needle and laser acupuncture. Biomed Eng Online, 9 : 78, 2010.

31）竹村香央里, 村山秀之, 福崎由美, 他：ヒ卜由来脳腫瘍細胞 の細胞増殖に対する $405 \mathrm{~nm}$ 低出力レーザー照射効果. 日レ 医誌, 31：382-388, 2011.

32）松澤紀彦，池島 嚴，藤林久仁子，他：LED 照射器による 各種ボンディングシステムを用いたコンポジットレジンの歯 質への接着強さについて. 日歯保存誌, 47 : 253-260, 2004.

33) Nomoto R, McCabe JF, Nitta K, et al: Relative efficiency of radiation sources for polymerization. Odontology, 97 : 109114,2009

34) Neumann MG, Miranda WG Jr, Schmitt CC, et al: Molar extinction coefficients and the photon absorption efficiency of dental photoinitiators and light curing units. J Dent, 33 : 525-532, 2005.

35) Arikawa $\mathrm{H}$, Takahashi $\mathrm{H}$, Kanie $\mathrm{T}$, et al: Effect of various visible light photoinitiators on the polymerization and color of light-activated resins. Dent Mater J, $28:$ 454-460, 2009.

36) Chae KH, Sun GJ: Phenylpropanedione; A new visible light photosensitizer for dental composite resin with higher effciency than camphorquinone. Bull Korean Chem Soc, 19 : 152-154, 1998.

37) Sun GJ, Chae KH: Properties of 2,3-botanedione and 1-phenyl-1,2-propanedione as new photosensitizers for visible light cured dental resin composites. Polymer, 41 : 6205-6212, 2000.

38）手島 渉, 野村雄二, 田中伸征, 他：紫色発光ダイオードを 用いて光硬化させた新規光重合開始剂添加歯科用レジンの反 応速度論的解析. 日歯保存誌, $47: 442-453,2004$.

39) Chen YC, Ferracane JL, Prahl SA: Quantum yield of conversion of the photoinitiator camphorquinone. Dent Mater, 23 : 655-664, 2007. 